\title{
Evaluation of factors controlling global secondary organic aerosol production from cloud processes
}

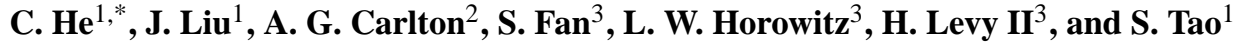 \\ ${ }^{1}$ College of Urban and Environmental Sciences, Peking University, Beijing, China \\ ${ }^{2}$ Department of Environmental Sciences, Rutgers University, New Brunswick, NJ, USA \\ ${ }^{3}$ Geophysical Fluid Dynamics Laboratory (GFDL), Princeton, NJ, USA \\ *now at: Department of Atmospheric and Oceanic Sciences, University of California at Los Angeles (UCLA), Los Angeles, \\ CA, USA
}

Correspondence to: J. Liu (jfliu@pku.edu.cn)

Received: 4 September 2012 - Published in Atmos. Chem. Phys. Discuss.: 11 October 2012

Revised: 21 January 2013 - Accepted: 6 February 2013 - Published: 19 February 2013

\begin{abstract}
Secondary organic aerosols (SOA) exert a significant influence on ambient air quality and regional climate. Recent field, laboratorial and modeling studies have confirmed that in-cloud processes contribute to a large fraction of SOA production with large space-time heterogeneity. This study evaluates the key factors that govern the production of cloud-process SOA ( $\mathrm{SOA}_{\text {cld }}$ ) on a global scale based on the GFDL coupled chemistry-climate model AM3 in which full cloud chemistry is employed. The association between $\mathrm{SOA}_{\text {cld }}$ production rate and six factors (i.e., liquid water content (LWC), total carbon chemical loss rate $\left(\mathrm{TC}_{\text {loss }}\right)$, temperature, $\mathrm{VOC} / \mathrm{NO}_{\mathrm{x}}, \mathrm{OH}$, and $\mathrm{O}_{3}$ ) is examined. We find that LWC alone determines the spatial pattern of $\mathrm{SOA}_{\text {cld }}$ production, particularly over the tropical, subtropical and temperate forest regions, and is strongly correlated with $\mathrm{SOA}_{\text {cld }}$ production. $\mathrm{TC}_{\text {loss }}$ ranks the second and mainly represents the seasonal variability of vegetation growth. Other individual factors are essentially uncorrelated spatiotemporally to $\mathrm{SOA}_{\text {cld }}$ production. We find that the rate of $\mathrm{SOA}_{\text {cld }}$ production is simultaneously determined by both $\mathrm{LWC}$ and $\mathrm{TC}_{\text {loss }}$, but responds linearly to LWC and nonlinearly (or concavely) to $\mathrm{TC}_{\text {loss }}$. A parameterization based on $\mathrm{LWC}$ and $\mathrm{TC}_{\text {loss }}$ can capture well the spatial and temporal variability of the process-based $\mathrm{SOA}_{\text {cld }}$ formation $\left(R^{2}=0.5\right)$ and can be easily applied to global three dimensional models to represent the SOA production from cloud processes.
\end{abstract}

\section{Introduction}

Secondary organic aerosol (SOA) is one of the most important components of atmospheric particulate matter, which has a significant influence on atmospheric chemistry and air quality and has potential toxicological effects (Kanakidou et al., 2005). These condensable compounds are produced through physical and chemical processing of both anthropogenic and biogenic volatile organic compounds (VOCs), including xylene, toluene, monoterpene, and isoprene, etc. (van Donkelaar et al., 2007; Henze et al., 2008). Among these species, aromatic hydrocarbons are estimated to be the most important anthropogenic SOA precursors (Pandis et al., 1992), while isoprene, monoterpene, and potentially sesquiterpene oxidation products are the predominant contributors to SOA production in rural forested areas (Guenther et al., 1995; Kanakidou et al., 2005).

Previous global modeling studies have overwhelmingly focused on the SOA formation in the gaseous phase. However, relying on gas-phase source alone, a number of modeling results tend to underestimate SOA concentrations by a significant degree (de Gouw et al., 2005; Heald et al., 2005; Volkamer et al., 2006). In-cloud processes are found to be responsible for a substantial fraction of SOA production (Carlton et al., 2008; Lim et al., 2010), indicating that SOA formed through cloud processes is a strong candidate to shrink the gap between observed and model-predicted organic aerosols. For instance, laboratorial experiments have demonstrated that organic acids (e.g., oxalic acid) and oligomers can be 
formed from glyoxal (Carlton et al., 2007), methylglyoxal (Altieri et al., 2008; Tan et al., 2010), pyruvic acid (Carlton et al., 2006), and acetic acid (Tan et al., 2012) through aqueousphase reactions in cloud. In addition, Ervens et al. (2004) suggested that cloud processes may act as a significant source of small dicarboxylic acids, which form SOA upon droplet evaporation. Lim et al. (2005) concluded that cloud processing of isoprene was an important contributor to SOA production.

A number of field measurements have confirmed SOA formation in the aqueous phase. Yu et al. (2005) showed a high correlation between oxalate and sulfate based on measurements in East Asia. In addition, Sorooshian et al. (2006) also found a strong correlation between measured oxalate and $\mathrm{SO}_{4}^{2-}$ aloft. Sulfate and oxalate are well-known to form during aqueous phase photooxidation from common watersoluble atmospheric gases. The strong correlations despite large differences in precursors and their emission sources, provide the evidence for a common production process (i.e., cloud production). Sorooshian et al. (2007) observed ubiquitous organic aerosol layers above clouds with enhanced organic acid levels and their data suggested that aqueousphase reactions to produce organic acids are a source of this elevated organic aerosol level. Moreover, based on several airborne field missions, organic acids and a larger body of oxygenated species with a mass spectral peak in $\mathrm{m} / \mathrm{z} 44$ were found to contribute to the total organic aerosol fraction, which increased as a function of RH and aerosol hygroscopicity, further indicating the role of aqueous-phase chemistry played on the formation organic aerosols (Sorooshian et al., 2010).

Recent modeling studies have also shown an improved model performance when cloud sources of SOA are included. For instance, Chen et al. (2007) found that when aqueous SOA production mechanisms were incorporated in the Community Multiscale Air Quality (CMAQ) model, domainwide surface SOA predictions increased by $9 \%$. Carlton et al. (2008) found that CMAQ model bias aloft against the observed organic carbon (OC) was reduced, when in-cloud SOA processes were included. Fu et al. (2009) predicted $11 \mathrm{TgC} \mathrm{yr}^{-1}$ SOA produced from aqueous phase processes based on GEOS-Chem and the variability in organic aerosols was better captured. Myriokefalitakis et al. (2011) found that the spatial and temporal distribution of the simulated oxalate agrees well with ambient observations at rural and remote locations when detailed aqueous-phase chemistry is employed.

In-cloud SOA formation involves a series of complicated processes: formation of water-soluble oxidation products (via oxidation of reactive organic compounds in the gas phase), partitioning into cloud droplets, then reacting further in the liquid phase (e.g., via photochemistry, acid catalysis, and with inorganic matter) to form low-volatility compounds (e.g., organic acids, oligomers, and organosulfates), which remain either completely or partially in the particle phase upon cloud droplet evaporation (Carlton et al., 2006; Guz- man et al., 2006; Perri et al., 2010). Furthermore, aqueousphase reactions can be categorized as radical reactions and non-radical reactions. Radical reactions involve a variety of atmospheric oxidants, including $\mathrm{OH}$ radicals, $\mathrm{NO}_{3}$ radicals, $\mathrm{O}_{3}, \mathrm{H}_{2} \mathrm{O}_{2}$, and can be initiated by photolysis (Lim et al., 2010). Non-radical reactions include hemiacetal formation (Liggio et al., 2005b; Loeffler et al., 2006), esterification via condensation reactions (Gao et al., 2004; Surratt et al., 2006; Surratt et al., 2007; Altieri et al., 2008), imine formation (De Haan et al., 2009a; De Haan et al., 2009c), anhydride formation (Gao et al., 2004), aldol condensation (Jang et al., 2002; Kalberer et al., 2004; Noziere and Cordova, 2008; Shapiro et al., 2009), and organosulfate formation (Liggio et al., 2005a; Surratt et al., 2007).

Presently only a few studies have attempted to quantitatively explore the factors that contribute to the formation of cloud SOA. For example, Ervens et al. (2008) used a cloud parcel model with explicit kinetic aqueous-phase chemistry to study the effects of initial $\mathrm{VOC} / \mathrm{NO}_{\mathrm{x}}$ ratio, cloud $\mathrm{PH}$, cloud contact time, and liquid water content (LWC) on $\mathrm{SOA}_{\text {cld }}$ formation from isoprene. They found that $\mathrm{SOA}_{\text {cld }}$ yield was a function of LWC and cloud contact time under different $\mathrm{VOC} / \mathrm{NO}_{\mathrm{x}}$ conditions. In addition, they found that $\mathrm{SOA}_{\mathrm{cld}}$ could be modeled in bulk cloud water without solving individual drop classes. This suggests implementation of aqueous phase organic chemistry and subsequent SOA formation in a larger scale model is an appropriate progression in the development of chemical schemes for atmospheric models. Liu et al. (2012) implemented a detailed cloud chemistry scheme into a climate model AM3 and evaluated the effects of cloud properties on the global $\mathrm{SOA}_{\text {cld }}$ production and distribution. They found that formation of $\mathrm{SOA}_{\text {cld }}$ varied significantly by time and space (i.e., dense production occurs over southern Africa and western Amazon tropical forests in DJF, but over southern China and the boreal forests in JJA) and is tied to the distribution of cloud water up to $400 \mathrm{hPa}$ above the surface.

This study is framed on Liu et al. (2012), but aims firstly to quantitatively understand the potential factors contributing significantly to the global spatial and temporal diversity of in-cloud formation of SOA, and secondly to establish a relationship between $\mathrm{SOA}_{\text {cld }}$ production and the key factors determining this process spatiotemporally. The approach is based on the global chemistry-climate model AM3 (Donner et al., 2011) with detailed multiphase chemistry developed in Liu et al. (2012, more description is given in Sect. 2.1). We describe the model and methods in Sect. 2, and then analyze the spatiotemporal relationship between $\mathrm{SOA}_{\text {cld }}$ production and factors determining in-cloud processes in Sect. 3. Results on the $\mathrm{SOA}_{\text {cld }}$ parameterization and its evaluation are given in Sect. 4. A variety of sensitivity tests on model parameters are shown in Sect. 5. Finally, conclusions are drawn in Sect. 6. 


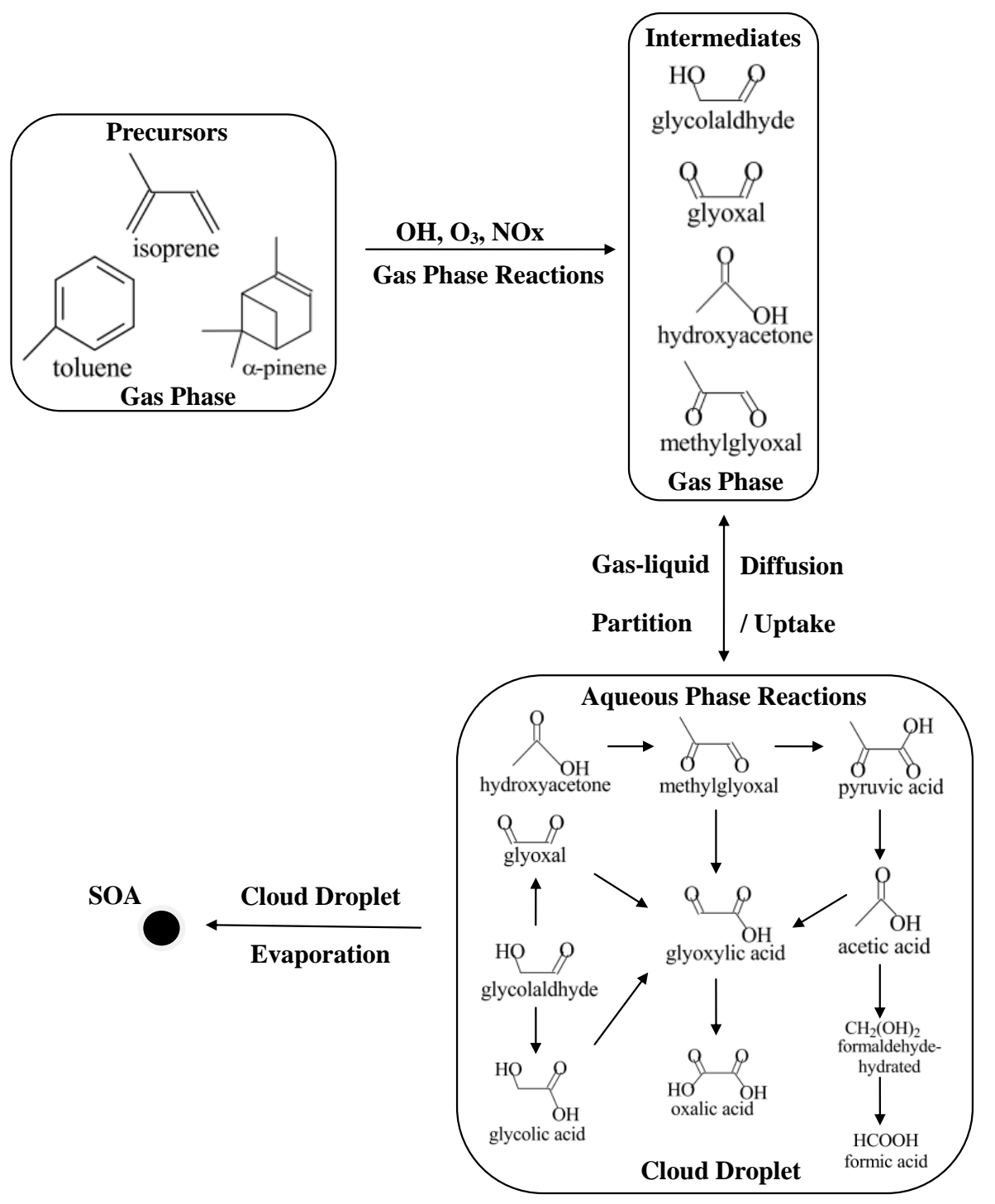

Fig. 1. Chemical mechanism for aqueous-phase formation of SOA.

\section{Method}

\subsection{Model description}

This study is based on the global coupled chemistry-climate model (AM3), developed in the Geophysical Fluid Dynamics Laboratory (GFDL). The goal of AM3 is to address emerging issues in climate change, including aerosol-cloud interactions, chemistry-climate interactions, and coupling between the troposphere and stratosphere (Donner et al., 2011). The dynamical core used in AM3 follows the finite-volume algorithms described in Lin and Rood (1997) and Lin (2004). AM3 implements a finite-volume dynamical core (Lin, 2004) on a cubed sphere grid (projection of a cube onto the surface of a sphere, Putman and Lin (2007)), replacing the latitudelongitude grid used in its previous version AM2. The model is configured with a horizontal resolution of $\mathrm{C} 48$. The total number of grid cells associated with this study is therefore $6 \times 48 \times 48=13824$ per layer, and the size of grid cells varies from $163 \mathrm{~km}$ (at 6 corners of the cubed sphere) to $231 \mathrm{~km}$ (near the center of each face) (Donner et al., 2011). The vertical co-ordinate in AM3 follows Simmons and Burridge (1981), and the number of layers is 48 . The uppermost level in AM3 has a pressure of $1 \mathrm{~Pa}$, a height of about $86 \mathrm{~km}$ above the sea level. AM3 predicts both shallow cumulus clouds (Bretherton et al., 2004) and deep convective clouds (Donner, 1993), besides a prognostic scheme of large-scale cloud condensate and volume fraction (Tiedtke, 1993; Rotstayn, 1997; Rotstayn et al., 2000). A prognostic scheme for droplet number is used to simulate the interactions between aerosols and large-scale liquid clouds (Ming et al., 2007), and sulfate, organic matter, and sea salt aerosols 
are treated as cloud condensation nuclei (CCN). In AM3, gas-phase chemistry is being updated from MOZART-2 to MOZART-4 chemistry mechanisms (Horowitz et al., 2003; Emmons et al., 2010) and aqueous chemistry is based on an optimized mechanism for sulfur chemistry, merged with the updated cloud SOA chemistry (Jacob, 1986; Pandis and Seinfeld, 1989; Lim et al., 2005; Tan et al., 2009; Liu et al., 2012). The coupled mechanism includes approximately 100 gas phase species, 50 aqueous phase species, and totally 370 kinetic expressions.

Figure 1 summarizes the pathway for in-cloud production of SOA in AM3. The primary physical and chemical processes associated with SOA production include oxidation of precursors, gas-liquid transport, aqueous-phase reactions, and cloud evaporation and $\mathrm{SOA}_{\text {cld }}$ formation.

\subsubsection{Oxidation of precursors}

Isoprene, terpenes, and aromatic compounds are the three representative precursors of $\mathrm{SOA}_{\text {cld }}$. Isoprene is the major organic compound emitted by plants with emission rates far exceeding those of other biogenic species. Monoterpenes (e.g., $\alpha$-pinene) are important biogenic VOCs emitted mainly by terrestrial vegetation and their oxidation products contribute significantly to SOA budget (Kavouras and Stephanou, 2002). Toluene is one of the most abundant aromatic compounds with average concentrations of 2-39 ppb in urban, $0.05-0.8 \mathrm{ppb}$ in rural and $0.01-0.25 \mathrm{ppb}$ in remote areas (Finlayson-Pitts and Pitts, 2000). These precursors are oxidized in the ambient air to form semi-volatile and lowvolatile organic species as well as water-soluble gases, such as glyoxal, methylglyoxal, glycolaldehyde, acetic acid and hydroxyacetone.

\subsubsection{Gas-liquid transport}

In the presence of clouds, the water-soluble gases formed in the gas phase will diffuse into or be absorbed by the cloud droplets. The calculation of gas-liquid partitioning is expressed kinetically (Liu et al., 2012) and is based on the mass balance of a species associated with chemical reactions, emissions, and deposition (Lim et al., 2005).

\subsubsection{Aqueous-phase reactions}

The dissolved gases (e.g., glyoxal, methylglyoxal, hydroxyacetone, and glycolaldehyde) will be oxidized further in the cloud water through various aqueous chemical reactions, leading to the formation of lower-volatility carboxylic acid (e.g., glycolic acid, glyoxylic acid, pyruvic acid and oxalic acid). During daytime, glyoxal will react with $\mathrm{OH}$ radicals to form oxalic acid in cloud droplets. Remaining glyoxal upon cloud evaporation will form oligomers through acid catalyzed hemiacetal formation (Lim et al., 2010). Aqueous phase oxidation of methylglyoxal by $\mathrm{OH}$ radical leads to the formation of oxalic acid and high molecular weight products
(Altieri et al., 2006; Carlton et al., 2006; Altieri et al., 2008). Other oxidation products include pyruvic acid (Stefan and Bolton, 1999) and oligomer through esterification (Carlton et al., 2007). Aqueous oxidation of glycolaldehyde via OH radical can form glyoxal and glycolic acid (Perri et al., 2009). Subsequent reactions create formic acid, glyoxylic acid, oxalic acid and oligomers (Perri et al., 2009). Acetic acid oxidation by $\mathrm{OH}$ radical will produce glyoxylic acid, glycolic acid, and oxalic acids in the liquid phase, but no oligomers will form (Tan et al., 2012). This may be because that acetic acid only forms unstable radicals which cannot involve the subsequent radical-radical reactions to form higher molecular weight products (Tan et al., 2012). Details on multiphase chemistry associated with SOA generation have been described by Liu et al. (2012).

\subsubsection{Cloud evaporation and $\mathrm{SOA}_{\text {cld }}$ formation}

When cloud droplets evaporate, low-volatility carboxylic acids as well as oligomers formed during cloud evaporation (Loeffler et al., 2006; De Haan et al., 2009b) are assumed to remain in the aerosol phase as SOA. Hence, the mass production of six $\mathrm{SOA}_{\text {cld }}$ species (i.e., glycolic acid, glyoxylic acid, pyruvic acid, oxalic acid, and two classes of oligomers formed by glyoxal and methylglyoxal) have been summed together to represent the total $\mathrm{SOA}_{\text {cld }}$ mass production.

\subsection{Model configuration}

In this study, the emission inventories used for both gas and aerosol species are obtained from the database developed for IPCC AR5 studies (Lamarque et al., 2010). Sea ice cover and sea surface temperature (SST) are prescribed using databases developed at the Hadley Center (Rayner et al., 2003). Cloud droplet lifetime is set to be $30 \mathrm{~min}$. Cloud droplet size and cloud fraction are using the model default values as described in Liu et al. (2012). Entrainment between the cloudy and non-cloudy areas is neglected here. We conduct a one-year simulation, and factors potentially influencing formation of SOA $_{\text {cld }}$ (see Sect. 2.1 and Fig. 1) are archived every 3 hours. Therefore, inside each model grid, the modeled production of $\mathrm{SOA}_{\text {cld }}$ in each timestep is physicochemically determined by the availability of cloud water, water-soluble gases, oxidants, etc.

\subsection{Spatiotemporal statistical analysis to develop parameterization of detailed cloud chemistry}

The significance of factors driving the variability of $\mathrm{SOA}_{\text {cld }}$ production $\left(\mathrm{P}_{\mathrm{SOAcld}}\right.$, expressed as the total SOA mass formed through cloud processes in one unit time, unit: $\mathrm{kg} \mathrm{m}^{-3} \mathrm{~s}^{-1}$ ) is examined by spatiotemporal statistical inference. Based on results from previous studies (e.g., Ervens et al., 2008 and Carlton et al., 2009) as well as the physical and chemical mechanisms of in-cloud formation of SOA (see Sect. 2.1 or Liu et al., 2012), the main factors expected to 
influence $\mathrm{SOA}_{\text {cld }}$ production include $\mathrm{LWC}$, temperature, the chemical loss rate of total carbon mass of primary precursors (i.e., isoprene, $\alpha$-pinene, and toluene), the concentration of $\mathrm{OH}$ and $\mathrm{O}_{3}$, and the $\mathrm{VOC}$ to $\mathrm{NO}_{\mathrm{x}}$ ratio $\left(\mathrm{VOC} / \mathrm{NO}_{\mathrm{x}}\right)$. Factors tied solely to the cloud chemistry simulation are ignored since this study targets understanding the extent to which non-linear processes of cloud chemistry can be explained externally.

As shown in Fig. 1, cloud water (i.e., LWC, unit: $\mathrm{kg}$ (water) $\mathrm{kg}(\text { air })^{-1}$ ) serves as the media where $\mathrm{SOA}_{\text {cld }}$ is formed. More cloud water is usually associated with more SOA $_{\text {cld }}$ production (Liu et al., 2012). Temperature governs the overall reaction rates and is shown in laboratory studies to be a key factor in SOA formation (Takekawa et al., 2003). VOC oxidation rate is an essential factor during the transformation among different organics. It indicates the availability of water-soluble gases (e.g., glyoxal and methylglyoxal) that are able to form $\mathrm{SOA}_{\text {cld }}$ (Fig. 1). Here we use total carbon chemical loss rate ( $\left.\mathrm{TC}_{\text {loss }}\right)$ of isoprene, $\alpha$-pinene, and toluene to represent the precursors' oxidation rate:

$$
\begin{aligned}
& \mathrm{TC}_{\text {loss }}\left(\mathrm{kgCm}^{-3} \cdot \mathrm{s}^{-1}\right) \\
& =0.012 \times\left(5 \times \mathrm{L}_{\text {isop }}+7 \times \mathrm{L}_{\text {tol }}+10 \times \mathrm{L}_{\text {pine }}\right)
\end{aligned}
$$

where $\mathrm{L}_{\text {isop, }} \mathrm{L}_{\text {pine, }}$ and $\mathrm{L}_{\text {tol }}$ are the loss rates (unit: mol m${ }^{-3} \mathrm{~s}^{-1}$ ) of isoprene, $\alpha$-pinene, and toluene, respectively.

The concentrations of $\mathrm{OH}$ and $\mathrm{O}_{3}$ (unit: $\mathrm{mol} \mathrm{m}^{-3}$ ) reflect the oxidation power of the atmosphere and can affect the reaction rate and pathway of SOA formation in both gaseous and liquid phases (Lim and Ziemann, 2005). VOC to $\mathrm{NO}_{\mathrm{x}}$ ratio is another factor that can influence oxidants and $\mathrm{SOA}_{\mathrm{cld}}$ yields, and has been found to be the most effective factor controlling $\mathrm{SOA}_{\text {cld }}$ yields in the cloud parcel model (Ervens et al., 2008). We ignore the factor of cloud fraction since it has been partially included in LWC when grid-box averaged LWC is used. Other factors related to cloud properties are not considered in this study and will be evaluated in followup studies.

The spatiotemporal dependence of $\mathrm{P}_{\text {SOAcld }}$ on a variety of individual meteorological and chemical factors and their combinations are examined based on correlation analysis and multiple regression models with/without nonlinear transformations (e.g., logarithm or grouping data by VOC to $\mathrm{NO}_{\mathrm{x}}$ ratios). We note that factors could be significantly involved in the non-linear production of $\mathrm{SOA}_{\mathrm{cld}}$ but show little direct spatiotemporal association to $\mathrm{P}_{\text {SOAcld }}$. Such factors will not typically be given strong weight by spatiotemporal statistical inference, consistent with our goal of identifying the key factors (or best predictors) best explaining the spatial and temporal diversity of $\mathrm{P}_{\text {SOAcld }}$. The final parameterization predicting $\mathrm{P}_{\text {SOAcld }}$ is explored based on both statistical inference and sensitivity analysis.

\section{Factors associated with spatiotemporal distribution of SOA cld production}

Spatiotemporal associations between daily $\mathrm{P}_{\text {SOAcld }}$ and each of the six factors (i.e., $\mathrm{LWC}, \mathrm{TC}_{\text {loss }}$, concentrations of $\mathrm{OH}$ and $\mathrm{O}_{3}, V O C / \mathrm{NO}_{\mathrm{x}}$, and temperature) are examined by a correlation analysis with a sample size of approximately 95 million. Here we apply a linear relationship to nonlinear processes of $\mathrm{P}_{\text {SOAcld }}$, but those non-linear processes are partially accounted for in the prognostic model simulation (though not perfectly). The results are shown in Table 1 (data are paired in space (horizontal and vertical) and time (daily average)) and are restricted to the following conditions: pressure level below $200 \mathrm{hPa}$, cloud volume fraction $>10^{-3}, \mathrm{LWC}>10^{-12} \mathrm{~kg}$ (water) $/ \mathrm{kg}$ (air), and $\mathrm{TC}_{\text {loss }}>10^{-22} \mathrm{kgC} \mathrm{m}^{-3} \mathrm{~s}^{-1}$ (approximately $61 \%$ of the spatial and temporal outputs are covered by the above threshold criteria, which accounts for more than $95 \%$ of global total $\mathrm{SOA}_{\text {cld }}$ production in the process-based simulation).

\subsection{Liquid water content}

LWC, which varies substantially in space and time, determines the amount of cloud water for water-soluble gases (WSG) to partition to and react in. As shown in Table 1, LWC shows the highest positive correlation $(r=0.32)$ with PSOAcld among the six factors, indicating a close association between $\mathrm{P}_{\text {SOAcld }}$ and LWC on the global scale. Figure 2a further depicts the spatial variability in correlation between $\mathrm{P}_{\text {SOAcld }}$ and LWC. High positive correlation $(r>0.7)$ is found over a broad area around the world at both lower and higher altitudes (see Fig. S1a in the Supplement). Over the forest regions in South Africa and South America, $\mathrm{P}_{\text {SOAcld }}$ correlates well with LWC $(r>0.9)$. This is because that when SOA precursors are abundant, LWC becomes the limiting factor determining the change of PSOAcld . Similarly, the high correlation over the Sahara regions may be also due to the lack of cloud water. $\mathrm{SOA}_{\mathrm{cld}}$ will form immediately in these areas whenever cloud is present, even though the amount of precursors is trivial compared to other places.

\subsection{Total carbon loss rate}

$\mathrm{TC}_{\text {loss }}$ represents the abundance of precursors and oxidation power, and thus indicates the production rate of water-soluble organic carbons (WSOC) in the gas phase. It ranks the second in terms of the spatiotemporal correlation with $\mathrm{SOA}_{\mathrm{cld}}$ production $(r=0.26$, see Table 1$)$. Figure $2 \mathrm{~b}$ shows the horizontal distribution of the $r$ values which are usually less than 0.7 except over Southeast China around $500 \mathrm{hPa}$ (see Figure S1b), Tibetan Plateau around $900 \mathrm{hPa}$, and a few locations over remote oceans, where $\mathrm{TC}_{\text {loss }}$ is strongly correlated with the $\mathrm{P}_{\text {SOAcld }}(r>0.7)$. This indicates that $\mathrm{TC}_{\text {loss }}$ acts more effectively there to facilitate $\mathrm{SOA}_{\text {cld }}$ formation. 
Table 1. Relative importance of factors influencing global spatiotemporal distribution of SOA $\mathrm{A}_{\text {cld }}$ production: correlation between daily $\mathrm{SOA}_{\text {cld }}$ production rate $\left(\mathrm{P}_{\mathrm{SOAcld}}\right)$ and each individual factor. Data are paired by space (i.e., horizontal and vertical) and time (daily average).

\begin{tabular}{lllllll}
\hline Correlation* & $\begin{array}{l}\mathrm{LWC} \\
\left(\mathrm{kg}_{\text {water }} / \mathrm{kg}_{\text {air }}\right)\end{array}$ & $\begin{array}{l}\mathrm{TC}_{\text {loss }} \\
\left(\mathrm{kg} \mathrm{m}^{-3} \mathrm{~s}^{-1}\right)\end{array}$ & $\begin{array}{l}\text { Temperature } \\
(\mathrm{K})\end{array}$ & $\begin{array}{l}\mathrm{O}_{3} \\
\left(\mathrm{~mol} / \mathrm{mol}_{\text {air }}\right)\end{array}$ & $\begin{array}{l}\mathrm{OH} \\
\left(\mathrm{mol} / \mathrm{mol}_{\text {air }}\right)\end{array}$ & $\begin{array}{l}\mathrm{VOC} / \mathrm{NO}_{\mathrm{x}} \\
\left(\mathrm{mol} \mathrm{mol}^{-1}\right)\end{array}$ \\
\hline$r$ & 0.32 & 0.26 & 0.036 & -0.001 & -0.008 & -0.006 \\
$r_{\text {log }}^{* *}$ & 0.74 & 0.54 & 0.37 & 0.08 & 0.16 & 0.33 \\
\hline
\end{tabular}

* All $p$ values are less than 0.001 .

** The correlation coefficients $(r)$ between $\log \left(\mathrm{P}_{\text {SOAcld }}\right)$ and the logarithm of each individual factor.
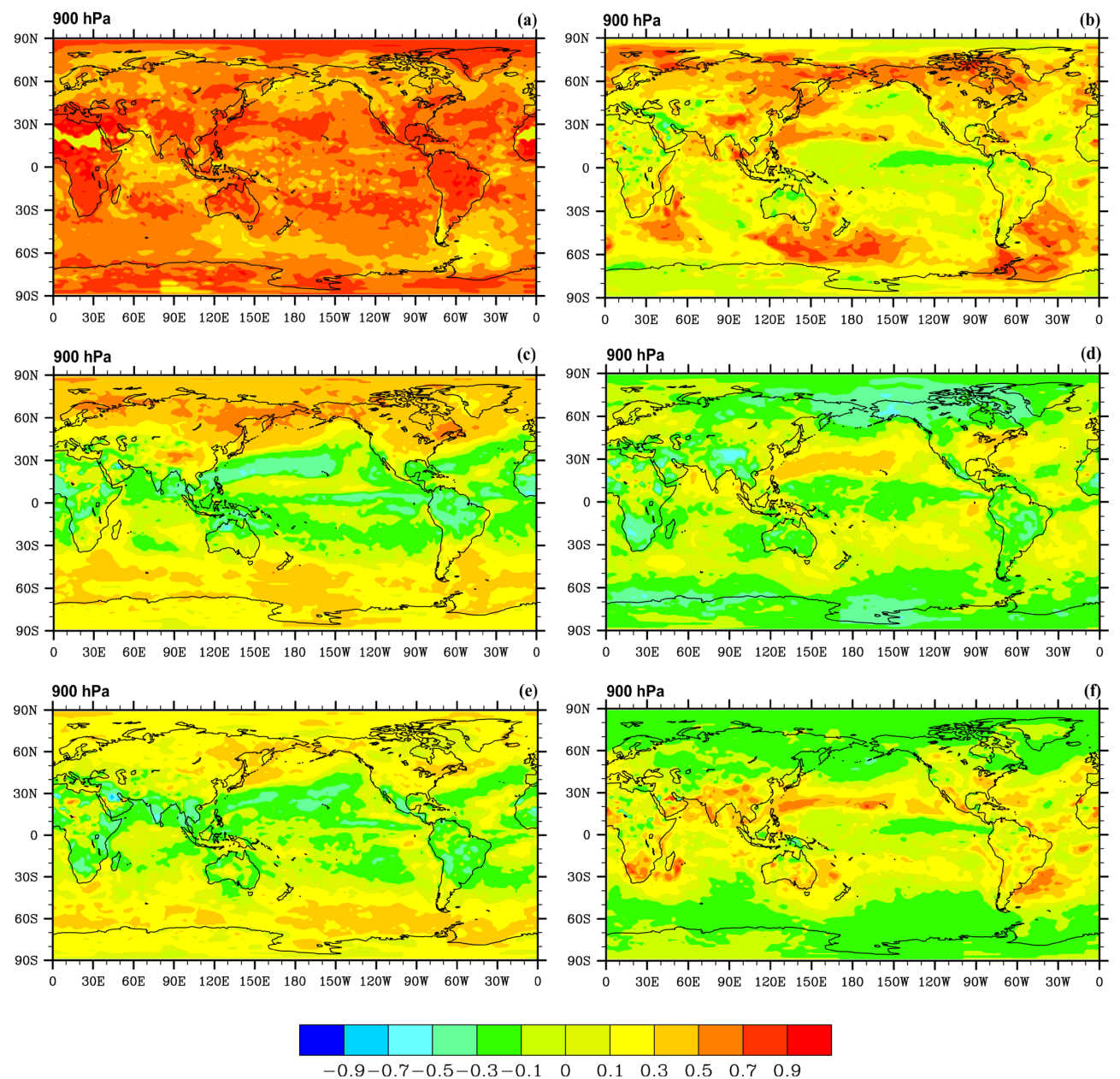

Fig. 2. Distribution of the correlation $(r)$ between $\mathrm{SOA}_{\text {cld }}$ production and (b) $\mathrm{LWC}$, (b) $\mathrm{TC}_{\text {loss }}$, (c) temperature, (d) $\mathrm{O}_{3}$, (e) $\mathrm{OH}$, (f) $\mathrm{VOC} \mathrm{NO}_{\mathrm{x}}$ at $900 \mathrm{hPa}$ around the world.

\subsection{Temperature}

As indicated in Table 1, temperature is not associated well with $\mathrm{P}_{\mathrm{SOAcld}}$ on the global scale. The correlation between $\mathrm{P}_{\text {SOAcld }}$ and temperature is typically small $(r<0.3)$ around the world (Fig. 2c). This suggests that the effects of temperature on $\mathrm{SOA}_{\mathrm{cld}}$ formation are either trivial or nonlinear. However, relatively high correlation $(r>0.5)$ is found over Northeast Asia, where $\mathrm{TC}_{\text {loss }}$ also plays an important role. This indicates that temperature maybe indirectly affects
$\mathrm{P}_{\text {SOAcld }}$ by influencing $\mathrm{TC}_{\text {loss }}$ or chemistry in this region. It is also possible that cloud formation and LWC are dependent on temperature in certain places like Northeast Asia.

\subsection{Other factors}

Similar to temperature, the effects of oxidants (i.e., $\mathrm{OH}$ and $\mathrm{O}_{3}$ ) on $\mathrm{P}_{\text {SOAcld }}$ are embedded in both gas-phase and aqueous-phase chemistry. Since $\mathrm{TC}_{\text {loss }}$ alone may only represent the gas-phase oxidation power, we evaluate the overall 
Table 2. Regression coefficients (b) and their standardized values (B) from multiple linear regression model (with log-transformation) between $\mathrm{P}_{\mathrm{SOAcld}}$ (unit: $\mathrm{kg} \mathrm{m}^{-3} \mathrm{~s}^{-1}$ ) and all six factors (or only $\mathrm{LWC}$ and $\mathrm{TC}_{\text {loss }}$ are considered).

\begin{tabular}{lllllll}
\hline & $\begin{array}{l}\mathrm{LWC} \\
\left(\mathrm{kg}_{\text {water }} / \mathrm{kg}_{\text {air }}\right)\end{array}$ & $\begin{array}{l}\mathrm{TC}_{\mathrm{loss}} \\
\left(\mathrm{kg} \mathrm{m}^{-3} \mathrm{~s}^{-1}\right)\end{array}$ & $\begin{array}{l}\text { Temperature } \\
(\mathrm{K})\end{array}$ & $\begin{array}{l}\mathrm{O}_{3} \\
\left(\mathrm{~mol} / \mathrm{mol}_{\mathrm{air}}\right)\end{array}$ & $\begin{array}{l}\mathrm{OH} \\
\left(\mathrm{mol} / \mathrm{mol}_{\mathrm{air}}\right)\end{array}$ & $\begin{array}{l}\mathrm{VOC} \mathrm{NO}_{\mathrm{x}} \\
\left(\mathrm{mol} \mathrm{mol}^{-1}\right)\end{array}$ \\
\hline $\mathrm{b}^{*}$ & $1.0409 \pm 0.0002$ & $0.3416 \pm 0.0003$ & $14.77 \pm 0.01$ & $-0.207 \pm 0.002$ & $-0.0106 \pm 0.0005$ & $0.0397 \pm 0.0004$ \\
$\mathrm{~B}^{* *}$ & 0.1704 & 0.0957 & 0.0571 & -0.0052 & -0.0015 & 0.0085 \\
$\mathrm{~b}^{* * *}$ & $1.0515 \pm 0.0002$ & $0.4175 \pm 0.0002$ & & & & \\
$\mathrm{~B}^{* * *}$ & 0.1721 & 0.1170 & & & & \\
\hline
\end{tabular}

$*^{*} \mathrm{~b}$ is the partial regression coefficients (i.e., the slope) of each individual factor with $95 \%$ confidence intervals. The regression model is constructed as $\log \left(\mathrm{P}_{\text {SOAcld }}\right) \sim \mathrm{b} 1 \log (\mathrm{LWC})+\mathrm{b} 2 \log \left(\mathrm{TC}_{\operatorname{loss}}\right)+\mathrm{b} 3 \log (\mathrm{Temp})+\mathrm{b} 4 \log \left(\mathrm{O}_{3}\right)+\mathrm{b} 5 \log (\mathrm{OH})+\mathrm{b} 6 \log \left(\mathrm{VOC} / \mathrm{NO}_{\mathrm{x}}\right)$

** B represents the standardized regression coefficients (i.e., the partial regression coefficients in units of standard deviation), which can be used to compare and explore the most effective factors.

*** Results are based only on the most effective factors (i.e., $\mathrm{LWC}$ and $\left.\mathrm{TC}_{\mathrm{loss}}\right)$. Now the regression model is $\log \left(\mathrm{P}_{\text {SOAcld }}\right)$

$\sim \mathrm{b} 1 \log (\mathrm{LWC})+\mathrm{b} 2 \log \left(\mathrm{TC}_{\text {loss }}\right)$. Please note, after transformed back from the pre-exponential coefficients, parameters in Eq. (2), namely $\alpha$ and $\beta$, are determined by an additional linear regression analysis, which are not shown here.

association of $\mathrm{O}_{3}$ and $\mathrm{OH}$ with $\mathrm{P}_{\text {SOAcld }}$ in Fig. $2 \mathrm{~d}$ and e, respectively. Both the cross-regional correlation (Table 1) and the spatial distribution of $r$ show little association between $\mathrm{P}_{\text {SOAcld }}$ and these two oxidants, indicating that oxidant alone is not linearly determining the overall gaseous and aqueous processes of $\mathrm{SOA}_{\text {cld }}$ formation.

$\mathrm{VOC} / \mathrm{NO}_{\mathrm{x}}$ governs the atmospheric oxidation capacity, but also plays an important role in controlling the oxidized organic species under low- $\mathrm{NO}_{\mathrm{x}}$ or high- $\mathrm{NO}_{\mathrm{x}}$ conditions (Carlton et al., 2009). Thus it is treated as an effective factor influencing $\mathrm{SOA}_{\text {cld }}$ production in Ervens et al., (2008). However, the cross-regional correlation between $\mathrm{VOC} / \mathrm{NO}_{\mathrm{x}}$ and $\mathrm{P}_{\text {SOAcld }}$ shows little association (Table 1). By examining the correlations over different locations, we find weak negative (positive) correlations distribute over mid- and high-latitude (tropical and subtropical) regions (Fig. 2f). This indicates that the effect of $\mathrm{VOC} / \mathrm{NO}_{\mathrm{x}}$ on $\mathrm{P}_{\mathrm{SOAcld}}$ is highly non-linear and may depend on locations, and therefore resolving a simple global relationship is difficult.

The above analysis indicates that $\mathrm{LWC}$ and $\mathrm{TC}_{\text {loss }}$ are most strongly correlated with $\mathrm{P}_{\text {SOAcld }}$. To understand the interdependence between the six factors, Table S1 in the Supplement lists their cross-correlation matrix. In general, neither LWC nor $\mathrm{TC}_{\text {loss }}$ is correlated well $(r<0.2)$ with the rest of the factors. In addition, to address the potential nonlinear association between $\mathrm{P}_{\text {SOAcld }}$ and individual factors, log-transformation is applied. Correlations between the logarithm of $\mathrm{P}_{\text {SOAcld }}\left(\log \left(\mathrm{P}_{\text {SOAcld }}\right)\right)$ and the logarithm of individual factors are shown in Table 1 . Higher correlations are found for all factors when log-transformation is employed, indicating significant nonlinear association between $\mathrm{P}_{\text {SOAcld }}$ and each factor. Table 2 shows the regression coefficients for multiple-factor linear regressions (with logtransformation) for two scenarios: (1) if all six listed factors are simultaneously associated with $\mathrm{P}_{\text {SOAcld }}$ and (2) when $\mathrm{LWC}$ and $\mathrm{TC}_{\text {loss }}$ are the only considered factors. From the standardized regression coefficients (i.e. the B values), LWC and $\mathrm{TC}_{\text {loss }}$ are still the two dominant factors contributing to global spatiotemporal variability of $\mathrm{P}_{\mathrm{SOAcld}}$. To address the non-linearity associated with $\mathrm{VOC} / \mathrm{NO}_{\mathrm{x}}$, we categorize the data by high $(>100)$, middle $(5-100)$ and low $(<5)$ $\mathrm{VOC} / \mathrm{NO}_{\mathrm{x}}$ conditions and perform the similar analysis for each subgroup. However, no significant improvement is observed (i.e., increase of $R^{2}$ is less than 0.05). This indicates that the effect of $\mathrm{VOC} / \mathrm{NO}_{\mathrm{x}}$ on $\mathrm{P}_{\text {SOAcld }}$ might change by location.

\section{Parameterization of $\mathrm{SOA}_{\text {cld }}$ production and its evaluation}

The larger correlations of $\mathrm{LWC}$ and $\mathrm{TC}_{\text {loss }}$ with $\mathrm{P}_{\text {SOAcld }}$ for spatiotemporally diverse data pairs suggest that instantaneous values of liquid water and the oxidative capacity of the atmosphere are the most critical factors considered in this study for PSOAcld . Effects of other factors could be important at specific location and time, but are generally inconsistent to the global spatiotemporal variation pattern of PSOAcld . Results of the multiple linear regression models (with transformation) in Table 2 indicate that $\mathrm{P}_{\text {SOAcld }}$ is driven by both $\mathrm{LWC}$ and $\mathrm{TC}_{\text {loss }}$ with the best-fit relationship shown in Eq. (2):

$\mathrm{P}_{\text {SOAcld }}=\alpha \times \mathrm{LWC} \times \mathrm{TC}_{\text {loss }}^{\gamma}+\beta$

where $\alpha$ (unit: $\left.\left(\mathrm{kg} \mathrm{m}^{-3} \mathrm{~s}^{-1}\right)^{(1-\gamma)}\right), \beta$ (unit: $\mathrm{kg} \mathrm{m}^{-3} \mathrm{~s}^{-1}$ ), and $\gamma$ are parameters determined by regression models. The best estimated global uniform values for $\alpha, \beta$, and $\gamma$ in Eq. (2) are respectively $4.66 \times 10^{-5}$ $\left(\mathrm{kg} \mathrm{m}^{-3} \mathrm{~s}^{-1}\right)^{0.6}, \quad 0.84 \times 10^{-17} \mathrm{~kg} \mathrm{~m}^{-3} \mathrm{~s}^{-1}$, and 0.4 for three-hour averaged data, and $5.5 \times 10^{-5}\left(\mathrm{~kg} \mathrm{~m}^{-3} \mathrm{~s}^{-1}\right)^{0.6}$, $0.84 \times 10^{-17} \mathrm{~kg} \mathrm{~m}^{-3} \mathrm{~s}^{-1}$, and 0.4 if applied in AM3 with a 30-minute model timestep. The slight change in $\alpha$ reflects the change in coincidence between the averaged LWC and $\mathrm{TC}_{\text {loss }}$ across different time resolution. The cross regional $R^{2}$ of Eq. (2) is approximately 0.5 , indicating that the combination of LWC and $\mathrm{TC}_{\text {loss }}$ alone can explain nearly half of the spatial and temporal variability of $\mathrm{P}_{\text {SOAcld }}$ 
in a global scale. To investigate factors that potentially co-vary with $\mathrm{LWC}$ and $\mathrm{TC}_{\text {loss }}$, other physically plausible relationships were investigated. In Ervens et al. (2008) cloud contact time ( $\propto$ cloud fraction) is significantly associated with cloud liquid water. In this study, if LWC is replaced by cloud fraction, $R^{2}$ will decrease by half. Therefore, we present the factors with the highest $R^{2}$. Equation (2) can be applied globally with the following restrictions (i.e., cloud volume fraction $>10^{-3}, \mathrm{LWC}>10^{-12} \mathrm{~kg}$ (water) $\mathrm{kg}(\text { air })^{-1}$, $\mathrm{TC}_{\text {loss }}>10^{-22} \mathrm{kgC} \mathrm{m}^{-3} \mathrm{~s}^{-1}$, and pressure level below $200 \mathrm{hPa}$ ).

Equation (2) also indicates that the production of $\mathrm{SOA}_{\text {cld }}$ is simultaneously determined by $\mathrm{LWC}$ and $\mathrm{TC}_{\text {loss }}$, which, respectively, represent the contribution from liquid-phase processes and gas-phase processes. The parameter $\alpha$ denotes the annual average intensity of chemical reactions in these processes. It determines the overall production efficiency of $\mathrm{SOA}_{\mathrm{cld}}$ and is tied to the whole multiphase process for SOA production. The parameter $\beta$ probably represents the influence of some physical processes, such as the transport of $\mathrm{SOA}_{\text {cld }}$ precursors from nearby regions. It may also represent the contribution from acetic acid, particularly over remote locations. Besides $\alpha$ and $\beta$, we find exponents of LWC and $\mathrm{TC}_{\text {loss }}$ are approximately 1 and 0.4 , respectively. This indicates that $\mathrm{P}_{\mathrm{SOAcld}}$ responds linearly to the spatiotemporal variability of cloud liquid water, but nonlinearly (or concavely) to the gas-phase oxidation of hydrocarbons. The $\gamma$ value reflects the complexity and combined effects of multiphase processes from the oxidation of VOCs to $\mathrm{SOA}_{\text {cld }}$ formation, including production of water-soluble species in the gas phase, the gas-liquid transport of oxidation products, and subsequent chemical reactions inside cloud droplets. Since $\gamma$ is less than 1, it may also suggest a competition for oxidants between gas-phase and liquid-phase chemistry to oxidize organic compounds as $\mathrm{TC}_{\text {loss }}$ increases.

After implementing Eq. (2) into AM3 to replace the detailed cloud chemistry scheme, the parameterized global $\mathrm{SOA}_{\text {cld }}$ production is $23.0 \mathrm{Tg} \mathrm{vr}^{-1}$, close to that simulated in AM3 using detailed cloud chemistry $\left(23.4 \mathrm{Tg} \mathrm{yr}^{-1}\right)$, as well as the results based on uptake coefficients $\left(\sim 22 \mathrm{Tg} \mathrm{yr}^{-1}, \mathrm{Fu}\right.$ et al. (2008) assuming $\mathrm{OM}: \mathrm{OC}=2$. We did not compare our results to Ervens et al., 2008 since implementation of the parameterization as suggested by Ervens et al. (2008) would require additional information (i.e., cloud contact time, not equivalent to cloud volume fraction) beyond the processes at play in AM3. Major differences between this study and Ervens et al., 2008 are summarized in Table $2 \mathrm{~S}$ in the Supplement). Specifically, the total $\mathrm{SOA}_{\text {cld }}$ tends to be underestimated in JJA $(-16 \%)$ and SON $(-6 \%)$, but overestimated in MAM $(12 \%)$ and DJF $(10 \%)$. Figure 3 compares the parameterized and process-based annual mean $\mathrm{P}_{\mathrm{SOAcld}}$ for all grid boxes around the world. The parameterized $\mathrm{P}_{\text {SOAcld }}$ is in general within a factor of 4 (representing $94 \%$ of global $\mathrm{SOA}_{\mathrm{cld}}$ mass production) but mostly within a factor of 2 (accounting for $66 \%$ of global $\mathrm{SOA}_{\mathrm{cld}}$ mass production) of these process-

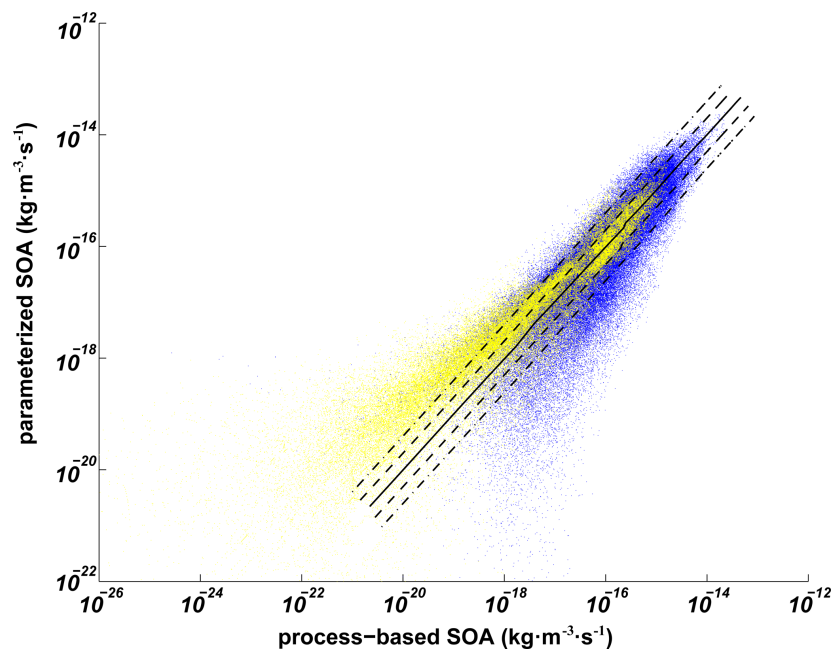

Fig. 3. Comparison between the parameterized and process-based annual mean $\mathrm{P}_{\text {SOAcld }}$ for every grid box below $200 \mathrm{hPa}$. Yellow dots indicate two polar regions as well as altitudes above $400 \mathrm{hPa}$. The solid line indicates the 1:1 line; the dashed lines indicate the 1:2 (or 2:1) lines; the dash-dot lines indicate the 1:4 (or 4:1) lines.

based estimations. The yellow dots in Fig. 3 represent remote locations (i.e., grids above $400 \mathrm{hPa}$ as well as two polar regions $\left(90^{\circ} \mathrm{S}-66.5^{\circ} \mathrm{S}, 66.5^{\circ} \mathrm{N}-90^{\circ} \mathrm{N}\right)$ below $\left.400 \mathrm{hPa}\right)$, whereas the blue part mostly represents tropical and midlatitude regions below $400 \mathrm{hPa}$, where $96 \%$ of global $\mathrm{SOA}_{\text {cld }}$ mass is produced. Even though the yellow dots represent $40 \%$ of the world grid cells, they only account for $\sim 4 \%$ of total global $\mathrm{SOA}_{\text {cld }}$ mass production.

Figure S2 in the supplementary material further decomposes the yellow dots in Fig. 3 into three parts: high-altitude regions (above $400 \mathrm{hPa})$, Antarctic regions $\left(90^{\circ} \mathrm{S}-66.5^{\circ} \mathrm{S}\right.$, below $400 \mathrm{hPa}$ ), and Arctic regions $\left(66.5^{\circ} \mathrm{N}-90^{\circ} \mathrm{N}\right.$, below $400 \mathrm{hPa}$ ). We find that $\mathrm{P}_{\text {SOAcld }}$ over the Arctic are predicted well by Eq. (2), and nearly $70 \%$ of grid cells are within a factor of 2 of the process-based estimations. In contrast, the PSOAcld over the Antarctic and high-altitude regions are systematically overestimated (more than $60 \%$ of these places are overestimated by more than a factor of 4). However, the $\mathrm{SOA}_{\text {cld }}$ mass production over these two regions are negligibly small ( $<2 \%$ of the total global $\mathrm{SOA}_{\text {cld }}$ mass production).

The process-based and parameterized annual column and zonal mean production of $\mathrm{SOA}_{\mathrm{cld}}$ are shown in Fig. 4. Both horizontal and vertical distributions of parameterized results are consistent well with the process-based estimations, except that a few underestimations are observed over the southeastern coast of South America and eastern Russia, and some slight overestimations over Europe and Southern Africa. In addition, the horizontal and vertical distribution of parameterized $\mathrm{P}_{\text {SOAcld }}$ follows a similar seasonal variation pattern with the process-based results (Figs. S3-S6 in the Supplement). However, the parameterized results are biased low (high) over northern mid-latitude regions in JJA (DJF) 
Table 3. The relative change in $\mathrm{SOA}_{\text {cld }}$ production as a $20 \%$ increase/decrease of each parameter in Eq. (2).

\begin{tabular}{crrrrrr}
\hline \multirow{2}{*}{ Parameter } & Relative change (\%) & \multicolumn{5}{c}{ Relative change (\%) in SOA cldproduction } \\
& & DJF & JJA & SON & MAM & Annually \\
\hline \multirow{2}{*}{$\alpha$} & 20 & 19.45 & 19.51 & 19.43 & 19.42 & 19.46 \\
& -20 & -19.45 & -19.51 & -19.43 & -19.42 & -19.46 \\
$\beta$ & 20 & 0.55 & 0.49 & 0.57 & 0.58 & 0.54 \\
& -20 & -0.55 & -0.49 & -0.57 & -0.58 & -0.54 \\
$\gamma$ & 20 & -88.66 & -88.34 & -88.96 & -88.63 & -88.66 \\
& -20 & 1280 & 1284 & 1282 & 1318 & 1290 \\
\hline
\end{tabular}
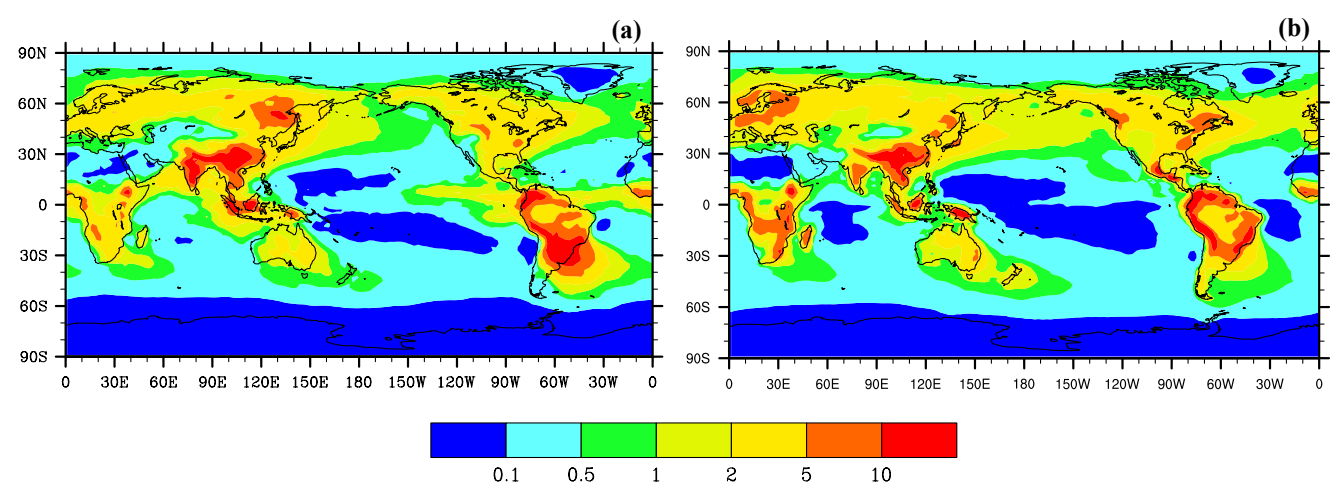

(c)

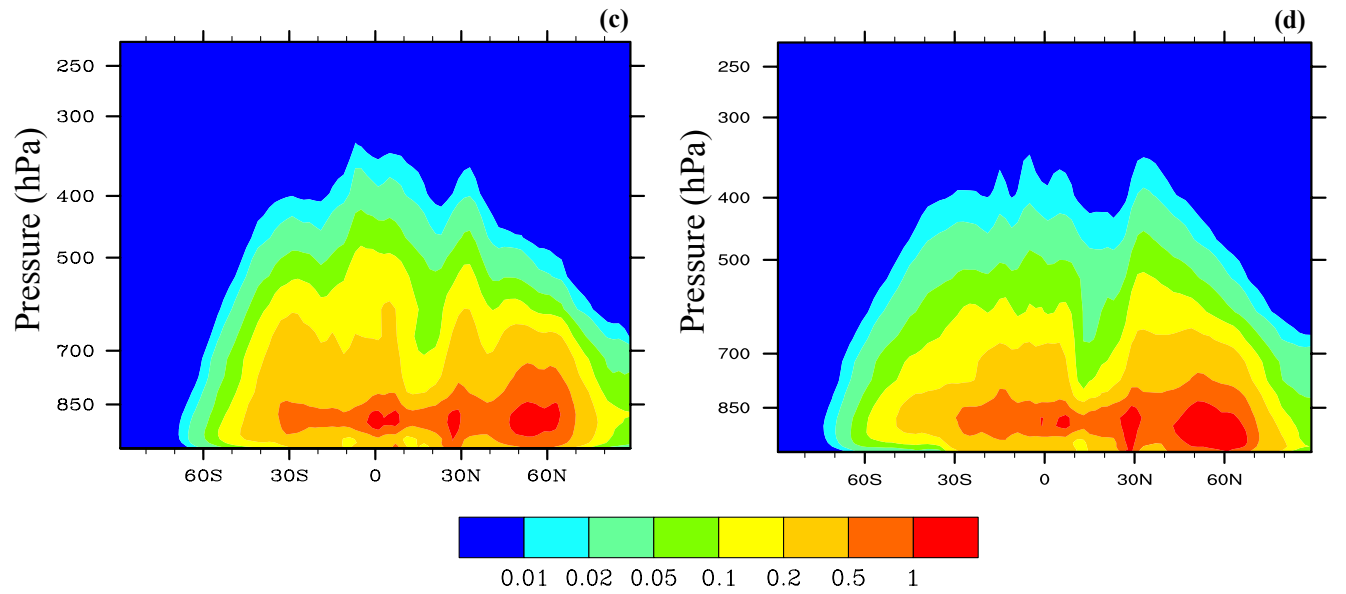

Fig. 4. Process-based $(\mathbf{a}, \mathbf{c})$ and parameterized $(b, d)$ annual averaged column production $\left(\mathrm{a}, \mathrm{b}, \mathrm{unit}\right.$ : $\left.\mathrm{ng} \mathrm{m}^{-2} \mathrm{~s}^{-1}\right)$ and zonal mean production $\left(\mathbf{c}, \mathbf{d}\right.$, unit: $\mathrm{pg} \mathrm{m}^{-3} \mathrm{~s}^{-1}$ ) of SOA from cloud processes.

between $800-950 \mathrm{hPa}$. This bias results from factors, such as temperature, and $\mathrm{VOC} / \mathrm{NO}_{\mathrm{x}}$, that may also influence $\mathrm{P}_{\mathrm{SOAcld}}$ there but are not incorporated in Eq. (2). Their unique effects on $\mathrm{P}_{\text {SOAcld }}$ over a specific region will be investigated in follow-up studies.

\section{Sensitivity and uncertainty analysis}

\subsection{Sensitivity tests on parameters}

In order to understand the sensitivity of parameterized $\mathrm{P}_{\text {SOAcld }}$ on individual parameters (i.e., $\alpha, \beta$, and $\gamma$ ) used in
Eq. (2), we conduct six sensitivity tests by either increasing or decreasing each parameter by $20 \%$. As shown in Table 3 , the global production of $\mathrm{SOA}_{\text {cld }}$ is determined linearly by $\alpha$, but is less influenced by $\beta$ (e.g., a $20 \%$ change in parameter $\beta$ only results in $\sim 0.5 \%$ change in global SOA $_{\text {cld }}$ production). Global $\mathrm{P}_{\text {SOAcld }}$ is also sensitive to $\gamma$, but exhibits a nonlinear relationship.

Figure 5 shows the relative change in column and zonal mean production of $\mathrm{SOA}_{\text {cld }}$ when each parameter is increased by $20 \%$ (the results show similar spatial pattern if these parameters are decreased by $20 \%$ ). As shown in Fig. 5a, b, $\mathrm{P}_{\text {SOAcld }}$ is sensitive to $\alpha$ all over the world except 

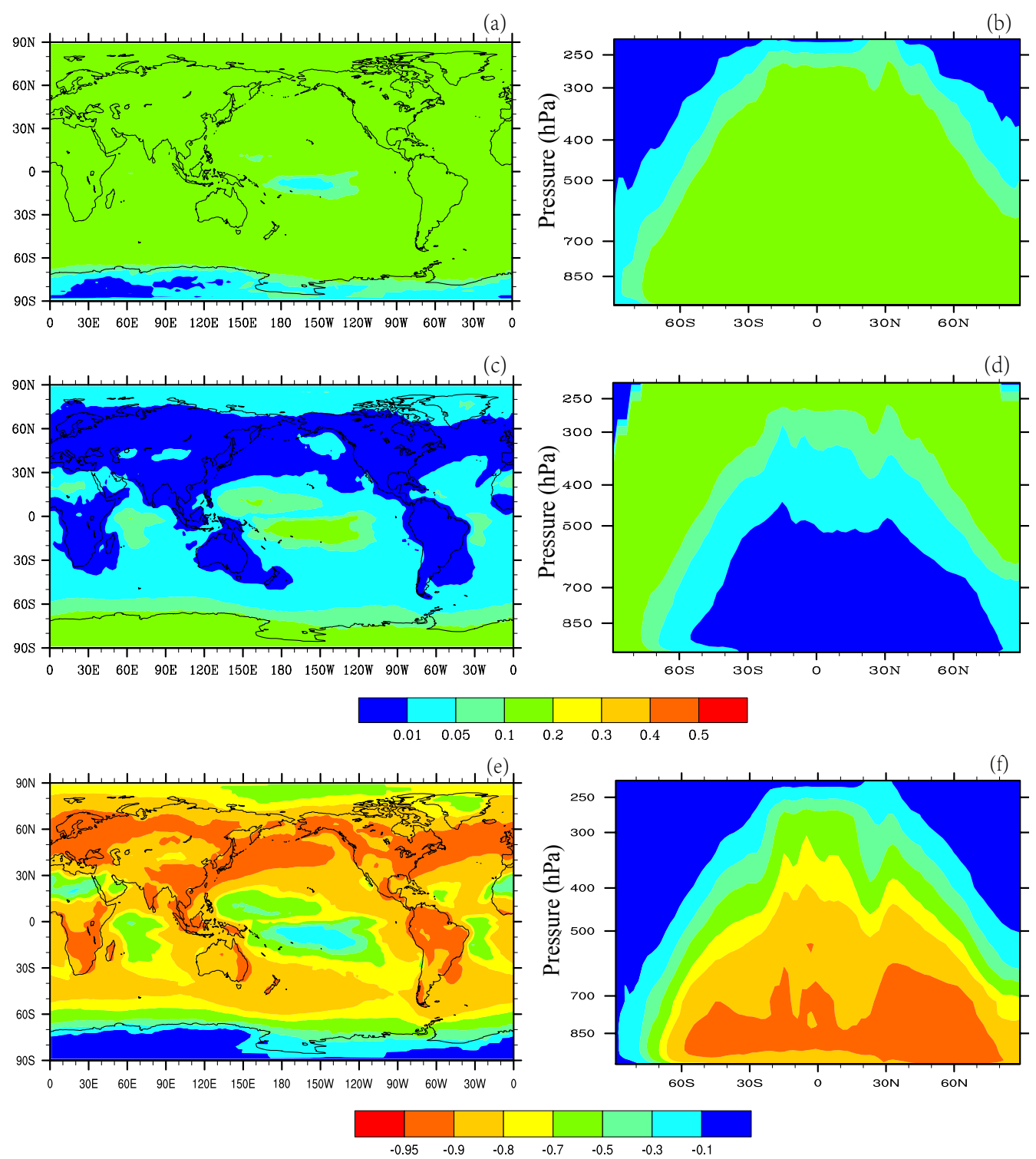

Fig. 5. Relative change of annual averaged column (a, c, e) and zonal mean $(\mathbf{b}, \mathbf{d}, \mathbf{f})$ production of SOA $\mathrm{S}_{\mathrm{cld}}$ as a result of $20 \%$ increase in parameter $\alpha(\mathbf{a}, \mathbf{b}), \beta(\mathbf{c}, \mathbf{d})$, and $\gamma(\mathbf{e}, \mathbf{f})$.

the Antarctic and high-altitude regions, where parameter $\beta$ has a dominant effect (Fig. 5c, d). Figure 5e, f show the change in $\mathrm{P}_{\text {SOAcld }}$ when parameter $\gamma$ is increased by $20 \%$. As inferred by Eq. (2), $\gamma$ is the only parameter leading to the nonlinear change in $\mathrm{P}_{\mathrm{SOAcld}}$, mainly driven by the seasonal change in $\mathrm{TC}_{\text {loss. }}$. Unlike $\alpha$ and $\beta$, effects of $\gamma$ on PSOAcld are particularly sensitive over the mid-latitude regions between $700-950 \mathrm{hPa}$. Similar to other $\mathrm{SOA}_{\text {cld }}$ parameterizations, implementation of Eq. (2) to global models with different time resolution may require slight change in parameter $\alpha$ (or $\beta$ ), to account for the difference in coincidence between LWC and $\mathrm{TC}_{\text {loss. }}$. However, the spatiotemporal pattern of $\mathrm{P}_{\text {SOAcld }}$ should be held according to Fig. 5 .

\subsection{Uncertainties}

Uncertainties of the parameterized $\mathrm{SOA}_{\text {cld }}$ production could be classified by the following three aspects: (1) the variance that is not explained by the linear regression model (e.g., the nonlinear effects of these factors on PSOAcld); (2) effects of cloud lifetime, cloud droplet size and cloud entrainment rate on $\mathrm{P}_{\text {SOAcld }}$ (which will be evaluated in the follow-up studies); (3) biases passing from the process-based model (i.e., simulations of cloud, transport and gas and liquid phase chemistry).

The $\mathrm{SOA}_{\text {cld }}$ formation includes a series of complicated physical and chemical processes and is influenced by many factors involving meteorological conditions, precursor 
emissions, atmospheric transport, photochemical and aqueous reactions. As mentioned in Sect. 4, biases still exist in the parameterized results. This is mainly due to inclusion in our parameterization of the production of $\mathrm{SOA}_{\text {cld }}$ (i.e., Eq. 2) only the two most important factors ( $\mathrm{LWC}$ and $\mathrm{TC}_{\text {loss }}$ ). For example, the underestimation of $\mathrm{P}_{\mathrm{SOAcld}}$ in Northeast Asia may be caused by neglecting the contribution from temperature, which has shown to be correlated with $\mathrm{P}_{\text {SOAcld }}$ over this region $(r>0.5)$. In addition, the three parameters in Eq. (2) just represent part of the detailed chemical and physical information and may not be able to fully capture all the processes of multiple phase chemistry for cloud SOA formation, such as partitioning, oxidation, and so on.

To reduce the bias of $\mathrm{SOA}_{\text {cld }}$ parameterization, one possible way is to improve the parameter $\alpha$ and $\gamma$ in Eq. (2). These two parameters directly control the overall magnitude of $\mathrm{SOA}_{\text {cld }}$ production, and are dependent on seasons. Therefore, further decomposing $\alpha$ and $\gamma$ by season could reduce the underestimation in JJA and SON and the overestimation in DJF and MAM. In addition, rather than relying on one set of global uniform parameters, Eq. (2) can be improved by a variety of sets of parameters conditioning on different locations (e.g., tropics, northern mid-latitudes, southern midlatitudes, polar regions, etc.). Furthermore, besides LWC and $\mathrm{TC}_{\text {loss }}$, more factors (e.g., temperature and $\mathrm{VOC} / \mathrm{NO}_{\mathrm{x}}$ ) could be used to improve the parameterization over a specific region (e.g., the northeastern Asia). Such detailed regional analysis is beyond the scope of this study, and will be investigated in our follow-up studies.

\section{Conclusions}

As a critical component of the atmospheric particulate matter burden, $\mathrm{SOA}_{\text {cld }}$ plays a crucial role in the atmospheric chemistry. Recently, in-cloud processes have been shown to contribute to atmospheric organic aerosol mass. Based on a detailed cloud chemistry scheme, Liu et al. (2012) found that substantial $\mathrm{SOA}_{\text {cld }}$ are formed in the tropical and midlatitude regions of the lower troposphere. This could potentially fill the gap between the observed and modeled organic aerosols at higher altitudes, as found in Carlton et al. (2008). Our study is based on the GFDL chemistry-climate model AM3 coupled with detailed cloud chemistry developed in Liu et al. (2012), but focuses mainly on firstly identifying the principal factors that govern the spatiotemporal distribution of $\mathrm{SOA}_{\text {cld }}$ formation, and secondly exploring a relationship of the relevant factors which can efficiently represent the global $\mathrm{SOA}_{\text {cld }}$ production with reasonable temporal and spatial variability.

We conduct a simulation of in-cloud production of SOA based on the GFDL coupled chemistry-climate model AM3 with detailed gaseous and aqueous phase chemistry. The spatiotemporal associations between $\mathrm{SOA}_{\text {cld }}$ production and each of six potential factors (i.e., $\mathrm{LWC}, \mathrm{TC}_{\mathrm{loss}}$, temperature,
$\mathrm{VOC} / \mathrm{NO}_{\mathrm{x}}, \mathrm{OH}$, and $\mathrm{O}_{3}$ ) are examined. We find that LWC determines the spatial pattern of $\mathrm{SOA}_{\text {cld }}$ formation, particularly over tropical, subtropical and temperate forest regions. $\mathrm{TC}_{\text {loss }}$ ranks the second and mostly represent the seasonal variability of vegetation growth and the rate of gas-phase chemical reactions. Other individual factors show little linear correlation to $\mathrm{SOA}_{\text {cld }}$ production. We find that globally the rate of $\mathrm{SOA}_{\text {cld }}$ production is simultaneously determined by both $\mathrm{LWC}$ and $\mathrm{TC}_{\text {loss }}$, but responds linearly to LWC and nonlinearly to $\mathrm{TC}_{\text {loss }}$ (i.e., $\mathrm{TC}_{\text {loss }}^{0.4}$ ). This parameterization can capture well the spatial and temporal variability of global process-based $\mathrm{SOA}_{\text {cld }}$ formation, especially in regions below $400 \mathrm{hPa}$ and places excluding remote oceans and the Antarctic region.

In order to identify the corresponding change of $\mathrm{SOA}_{\text {cld }}$ production resulting from the perturbations of each parameter (i.e., $\alpha, \beta$ and $\gamma$ in Eq. 2), we conduct six sensitivity tests in which each parameter is either increased or decreased by $20 \%$ while keeping the other two parameters unchanged. We find that the $\mathrm{SOA}_{\text {cld }}$ production is sensitive to parameters $\alpha$ and $\gamma$ in most areas around the world. But the parameter $\beta$ has dominant contributions to the $\mathrm{SOA}_{\text {cld }}$ production over the Antarctic and high-altitude regions where $\mathrm{LWC}$ and $\mathrm{TC}_{\text {loss }}$ are very small.

This parameterized in-cloud SOA production can be easily applied in global chemical transport models (e.g., work well in MOZART-4 driven with NCEP reanalysis meteorology) or global climate models to efficiently and reasonably simulate SOA production from cloud processes.

\section{Supplementary material related to this article is available online at: http://www.atmos-chem-phys.net/13/ 1913/2013/acp-13-1913-2013-supplement.pdf.}

Acknowledgements. We thank two anonymous reviewers for their thoughtful comments and helpful suggestions. This work was supported by funding from the National Natural Science Foundation of China under awards 41222011 and 41130754 as well as the "863" Hi-Tech R\&D Program of China under Grant No. 2012AA063303 and in part by the US EPA Grant 83504101.

Edited by: F. Yu

\section{References}

Altieri, K. E., Carlton, A. G., Lim, H. J., Turpin, B. J., and Seitzinger, S. P.: Evidence for oligomer formation in clouds: Reactions of isoprene oxidation products, Environ. Sci. Technol., 40, 4956-4960, doi:10.1021/Es052170n, 2006.

Altieri, K. E., Seitzinger, S. P., Carlton, A. G., Turpin, B. J., Klein, G. C., and Marshall, A. G.: Oligomers formed through in-cloud methylglyoxal reactions: Chemical composition, properties, and mechanisms investigated by ultra-high resolution 
FT-ICR mass spectrometry, Atmos. Environ., 42, 1476-1490, doi:10.1016/j.atmosenv.2007.11.015, 2008.

Bretherton, C. S., McCaa, J. R., and Grenier, H.: A new parameterization for shallow cumulus convection and its application to marine subtropical cloud-topped boundary layers. Part I: Description and 1D results, Mon. Weather Rev., 132, 864-882, 2004.

Carlton, A. G., Turpin, B. J., Lim, H. J., Altieri, K. E., and Seitzinger, S.: Link between isoprene and secondary organic aerosol (SOA): Pyruvic acid oxidation yields low volatility organic acids in clouds, Geophys. Res. Lett., 33, L06822, doi:10.1029/2005GL025374, 2006.

Carlton, A. G., Turpin, B. J., Altieri, K. E., Seitzinger, S., Reff, A., Lim, H. J., and Ervens, B.: Atmospheric oxalic acid and SOA production from glyoxal: Results of aqueous photooxidation experiments, Atmos. Environ., 41, 7588-7602, 2007.

Carlton, A. G., Turpin, B. J., Altieri, K. E., Seitzinger, S. P., Mathur, R., Roselle, S. J., and Weber, R. J.: CMAQ Model Performance Enhanced When In-Cloud Secondary Organic Aerosol is Included: Comparisons of Organic Carbon Predictions with Measurements, Environ. Sci. Technol., 42, 8798-8802, 2008.

Carlton, A. G., Wiedinmyer, C., and Kroll, J. H.: A review of Secondary Organic Aerosol (SOA) formation from isoprene, Atmos. Chem. Phys., 9, 4987-5005, doi:10.5194/acp-9-4987-2009, 2009.

Chen, J., Griffin, R. J., Grini, A., and Tulet, P.: Modeling secondary organic aerosol formation through cloud processing of organic compounds, Atmos. Chem. Phys., 7, 5343-5355, doi:10.5194/acp-7-5343-2007, 2007.

de Gouw, J. A., Middlebrook, A. M., Warneke, C., Goldan, P. D., Kuster, W. C., Roberts, J. M., Fehsenfeld, F. C., Worsnop, D. R., Canagaratna, M. R., Pszenny, A. A. P., Keene, W. C., Marchewka, M., Bertman, S. B., and Bates, T. S.: Budget of organic carbon in a polluted atmosphere: Results from the New England Air Quality Study in 2002, J. Geophys. Res.-Atmos., 110, D16305, doi:10.1029/2004JD005623, 2005.

De Haan, D. O., Tolbert, M. A., and Jimenez, J. L.: Atmospheric condensed-phase reactions of glyoxal with methylamine, Geophys. Res. Lett., 36, L11819, doi:10.1029/2009GL037441, 2009a.

De Haan, D. O., Corrigan, A. L., Tolbert, M. A., Jimenez, J. L., Wood, S. E., and Turley, J. J.: Secondary Organic Aerosol Formation by Self-Reactions of Methylglyoxal and Glyoxal in Evaporating Droplets, Environ. Sci. Technol., 43, 8184-8190, 2009 b.

De Haan, D. O., Corrigan, A. L., Smith, K. W., Stroik, D. R., Turley, J. J., Lee, F. E., Tolbert, M. A., Jimenez, J. L., Cordova, K. E., and Ferrell, G. R.: Secondary Organic Aerosol-Forming Reactions of Glyoxal with Amino Acids, Environ. Sci. Technol., 43, 28182824, 2009c.

Donner, L. J.: A Cumulus Parameterization Including Mass Fluxes, Vertical Momentum Dynamics, and Mesoscale Effects, J. Atmos. Sci., 50, 889-906, 1993.

Donner, L. J., Wyman, B. L., Hemler, R. S., Horowitz, L. W., Ming, Y., Zhao, M., Golaz, J. C., Ginoux, P., Lin, S. J., Schwarzkopf, M. D., Austin, J., Alaka, G., Cooke, W. F., Delworth, T. L., Freidenreich, S. M., Gordon, C. T., Griffies, S. M., Held, I. M., Hurlin, W. J., Klein, S. A., Knutson, T. R., Langenhorst, A. R., Lee, H. C., Lin, Y. L., Magi, B. I., Malyshev, S. L., Milly, P. C. D., Naik, V., Nath, M. J., Pincus, R., Ploshay, J. J., Ramaswamy, V., Seman, C. J., Shevliakova, E., Sirutis, J. J., Stern, W. F., Stouffer,
R. J., Wilson, R. J., Winton, M., Wittenberg, A. T., and Zeng, F. R.: The Dynamical Core, Physical Parameterizations, and Basic Simulation Characteristics of the Atmospheric Component AM3 of the GFDL Global Coupled Model CM3, J. Climate, 24, 34843519, 2011.

Emmons, L. K., Walters, S., Hess, P. G., Lamarque, J.-F., Pfister, G. G., Fillmore, D., Granier, C., Guenther, A., Kinnison, D., Laepple, T., Orlando, J., Tie, X., Tyndall, G., Wiedinmyer, C., Baughcum, S. L., and Kloster, S.: Description and evaluation of the Model for Ozone and Related chemical Tracers, version 4 (MOZART-4), Geosci. Model Dev., 3, 43-67, doi:10.5194/gmd3-43-2010, 2010.

Ervens, B., Feingold, G., Frost, G. J., and Kreidenweis, S. M.: A modeling study of aqueous production of dicarboxylic acids: 1. Chemical pathways and speciated organic mass production, J. Geophys. Res.-Atmos., 109, D15205, doi:10.1029/2003JD004387, 2004.

Ervens, B., Carlton, A. G., Turpin, B. J., Altieri, K. E., Kreidenweis, S. M., and Feingold, G.: Secondary organic aerosol yields from cloud-processing of isoprene oxidation products, Geophys. Res. Lett., 35, L02816, doi:10.1029/2007GL031828, 2008.

Finlayson-Pitts, B. and Pitts, J. N.: Chemistry of the Upper and Lower Atmosphere: Theory, Experiments, and Applications, Academic, San Diego, CA, USA, 586-591, 2000.

Fu, T. M., Jacob, D. J., and Heald, C. L.: Aqueous-phase reactive uptake of dicarbonyls as a source of organic aerosol over eastern North America, Atmos. Environ., 43, 1814-1822, 2009.

Gao, S., Ng, N. L., Keywood, M., Varutbangkul, V., Bahreini, R., Nenes, A., He, J. W., Yoo, K. Y., Beauchamp, J. L., Hodyss, R. P., Flagan, R. C., and Seinfeld, J. H.: Particle phase acidity and oligomer formation in secondary organic aerosol, Environ. Sci. Technol., 38, 6582-6589, 2004.

Guenther, A., Hewitt, C. N., Erickson, D., Fall, R., Geron, C., Graedel, T., Harley, P., Klinger, L., Lerdau, M., Mckay, W. A., Pierce, T., Scholes, B., Steinbrecher, R., Tallamraju, R., Taylor, J., and Zimmerman, P.: A Global-Model of Natural Volatile Organic-Compound Emissions, J. Geophys. Res.-Atmos., 100, 8873-8892, 1995.

Guzman, M. I., Colussi, A. J., and Hoffmann, M. R.: Photoinduced oligomerization of aqueous pyruvic acid, J. Phys. Chem. A, 110, 3619-3626, 2006

Heald, C. L., Jacob, D. J., Park, R. J., Russell, L. M., Huebert, B. J., Seinfeld, J. H., Liao, H., and Weber, R. J.: A large organic aerosol source in the free troposphere missing from current models, Geophys. Res. Lett., 32, L18809, doi:10.1029/2005GL02383, 2005.

Henze, D. K., Seinfeld, J. H., Ng, N. L., Kroll, J. H., Fu, T. M., Jacob, D. J., and Heald, C. L.: Global modeling of secondary organic aerosol formation from aromatic hydrocarbons: highvs. low-yield pathways, Atmos. Chem. Phys., 8, 2405-2420, doi:10.5194/acp-8-2405-2008, 2008.

Horowitz, L. W., Walters, S., Mauzerall, D. L., Emmons, L. K., Rasch, P. J., Granier, C., Tie, X. X., Lamarque, J. F., Schultz, M. G., Tyndall, G. S., Orlando, J. J., and Brasseur, G. P.: A global simulation of tropospheric ozone and related tracers: Description and evaluation of MOZART, version 2, J. Geophys. Res.-Atmos., 108, 4784, doi:10.1029/2002JD002853, 2003.

Jacob, D. J.: Chemistry of Oh in Remote Clouds and Its Role in the Production of Formic-Acid and Peroxymonosulfate, J. Geophys. Res.-Atmos., 91, 9807-9826, 1986. 
Jang, M. S., Czoschke, N. M., Lee, S., and Kamens, R. M.: Heterogeneous atmospheric aerosol production by acid-catalyzed particle-phase reactions, Science, 298, 814-817, 2002.

Kalberer, M., Paulsen, D., Sax, M., Steinbacher, M., Dommen, J., Prevot, A. S. H., Fisseha, R., Weingartner, E., Frankevich, V., Zenobi, R., and Baltensperger, U.: Identification of polymers as major components of atmospheric organic aerosols, Science, 303, 1659-1662, 2004.

Kanakidou, M., Seinfeld, J. H., Pandis, S. N., Barnes, I., Dentener, F. J., Facchini, M. C., Van Dingenen, R., Ervens, B., Nenes, A., Nielsen, C. J., Swietlicki, E., Putaud, J. P., Balkanski, Y., Fuzzi, S., Horth, J., Moortgat, G. K., Winterhalter, R., Myhre, C. E. L., Tsigaridis, K., Vignati, E., Stephanou, E. G., and Wilson, J.: Organic aerosol and global climate modelling: a review, Atmos. Chem. Phys., 5, 1053-1123, 2005,

http://www.atmos-chem-phys.net/5/1053/2005/.

Kavouras, I. G. and Stephanou, E. G.: Direct evidence of atmospheric secondary organic aerosol formation in forest atmosphere through heteromolecular nucleation, Environ. Sci. Technol., 36, 5083-5091, 2002.

Lamarque, J. F., Bond, T. C., Eyring, V., Granier, C., Heil, A., Klimont, Z., Lee, D., Liousse, C., Mieville, A., Owen, B., Schultz, M. G., Shindell, D., Smith, S. J., Stehfest, E., Van Aardenne, J., Cooper, O. R., Kainuma, M., Mahowald, N., McConnell, J. R., Naik, V., Riahi, K., and van Vuuren, D. P.: Historical (1850-2000) gridded anthropogenic and biomass burning emissions of reactive gases and aerosols: methodology and application, Atmos. Chem. Phys., 10, 7017-7039, doi:10.5194/acp10-7017-2010, 2010.

Liggio, J., Li, S. M., and Mclaren, R.: Heterogeneous reactions of glyoxal on particulate matter: Identification of acetals and sulfate esters, Environ. Sci. Technol., 39, 1532-1541, 2005 a.

Liggio, J., Li, S. M., and Mclaren, R.: Reactive uptake of glyoxal by particulate matter, J. Geophys. Res.-Atmos., 110, D10304, doi:10.1029/2004JD005113, 2005b.

Lim, H. J., Carlton, A. G., and Turpin, B. J.: Isoprene forms secondary organic aerosol through cloud processing: Model simulations, Environ. Sci. Technol., 39, 4441-4446, 2005.

Lim, Y. B., and Ziemann, P. J.: Products and mechanism of secondary organic aerosol formation from reactions of n-alkanes with $\mathrm{OH}$ radicals in the presence of $\mathrm{NO}_{\mathrm{x}}$, Environ. Sci. Technol., 39, 9229-9236, 2005.

Lim, Y. B., Tan, Y., Perri, M. J., Seitzinger, S. P., and Turpin, B. J.: Aqueous chemistry and its role in secondary organic aerosol (SOA) formation, Atmos. Chem. Phys., 10, 1052110539, doi:10.5194/acp-10-10521-2010, 2010.

Lin, S. J.: A “vertically Lagrangian" finite-volume dynamical core for global models, Mon. Weather Rev., 132, 2293-2307, 2004.

Lin, S. J. and Rood, R. B.: An explicit flux-form semi-Lagrangian shallow-water model on the sphere, Q. J. Roy. Meteor. Soc., 123, 2477-2498, 1997.

Liu, J. F., Horowitz, L. W., Carlton, A. G.: Global incloud production of secondary organic aerosols: Implementation of a detailed chemical mechanism in the GFDL atmospheric model AM3, J. Geophys. Res.-Atmos., 117, D15303, doi:10.1029/2012JD017838, 2012.

Loeffler, K. W., Koehler, C. A., Paul, N. M., and De Haan, D. O.: Oligomer formation in evaporating aqueous glyoxal and methyl glyoxal solutions, Environ. Sci. Technol., 40, 6318-6323, 2006.
Ming, Y., Ramaswamy, V., Donner, L. J., Phillips, V. T. J., Klein, S. A., Ginoux, P. A., and Horowitz, L. W.: Modeling the interactions between aerosols and liquid water clouds with a self-consistent cloud scheme in a general circulation model, J. Atmos. Sci., 64, 1189-1209, 2007.

Myriokefalitakis, S., Tsigaridis, K., Mihalopoulos, N., Sciare, J., Nenes, A., Kawamura, K., Segers, A., and Kanakidou, M.: Incloud oxalate formation in the global troposphere: a 3-D modeling study, Atmos. Chem. Phys., 11, doi:10.5194/acp-11-57612011, 5761-5782, 2011.

Noziere, B. and Cordova, A.: A kinetic and mechanistic study of the amino acid catalyzed aldol condensation of acetaldehyde in aqueous and salt solutions, J. Phys. Chem. A, 112, 2827-2837, 2008.

Pandis, S. N. and Seinfeld, J. H.: Sensitivity Analysis of a Chemical Mechanism for Aqueous-Phase Atmospheric Chemistry, J. Geophys. Res.-Atmos., 94, 1105-1126, 1989.

Pandis, S. N., Harley, R. A., Cass, G. R., and Seinfeld, J. H.: Secondary Organic Aerosol Formation and Transport, Atmos. Environ. a-Gen, 26, 2269-2282, 1992.

Perri, M. J., Seitzinger, S., and Turpin, B. J.: Secondary organic aerosol production from aqueous photooxidation of glycolaldehyde: Laboratory experiments, Atmos. Environ., 43, 1487-1497, 2009.

Perri, M. J., Lim, Y. B., Seitzinger, S. P., and Turpin, B. J.: Organosulfates from glycolaldehyde in aqueous aerosols and clouds: Laboratory studies, Atmos. Environ., 44, 2658-2664, 2010.

Putman, W. M., and Lin, S. H.: Finite-volume transport on various cubed-sphere grids, J. Comput. Phys., 227, 55-78, doi:10.1016/j.jcp.2007.07.022, 2007.

Rayner, N. A., Parker, D. E., Horton, E. B., Folland, C. K., Alexander, L. V., Rowell, D. P., Kent, E. C., and Kaplan, A.: Global analyses of sea surface temperature, sea ice, and night marine air temperature since the late nineteenth century, J. Geophys. Res.Atmos., 108, 4407, doi:10.1029/2002JD002670, 2003.

Rotstayn, L. D.: A physically based scheme for the treatment of stratiform clouds and precipitation in large-scale models .1. Description and evaluation of the microphysical processes, Q. J. Roy. Meteor. Soc., 123, 1227-1282, 1997.

Rotstayn, L. D., Ryan, B. F., and Katzfey, J. J.: A scheme for calculation of the liquid fraction in mixed-phase stratiform clouds in large-scale models, Mon. Weather Rev., 128, 1070-1088, 2000.

Shapiro, E. L., Szprengiel, J., Sareen, N., Jen, C. N., Giordano, M. R., and McNeill, V. F.: Light-absorbing secondary organic material formed by glyoxal in aqueous aerosol mimics, Atmos. Chem Phys., 9, 2289-2300, doi:10.5194/acp-9-2289-2009, 2009.

Simmons, A. J. and Burridge, D. M.: An Energy and AngularMomentum Conserving Vertical Finite-Difference Scheme and Hybrid Vertical-Coordinates, Mon. Weather Rev., 109, 758-766, 1981.

Sorooshian, A., Lu, M. L., Brechtel, F. J., Jonsson, H., Feingold, G., Flagan, R. C., and Seinfeld, J. H.: On the source of organic acid aerosol layers above clouds, Environ. Sci. Technol., 41, 46474654, 2007.

Sorooshian, A., Murphy, S. M., Hersey, S., Bahreini, R., Jonsson, H., Flagan, R. C., and Seinfeld, J. H.: Constraining the contribution of organic acids and AMS m/z 44 to the organic aerosol budget: On the importance of meteorology, aerosol 
hygroscopicity, and region, Geophys. Res. Lett., 37, L21807, doi:10.21029/22010g1044951, 2010.

Sorooshian, A., Varutbangkul, V., Brechtel, F. J., Ervens, B., Feingold, G., Bahreini, R., Murphy, S. M., Holloway, J. S., Atlas, E. L., Buzorius, G., Jonsson, H., Flagan, R. C., and Seinfeld, J. H.: Oxalic acid in clear and cloudy atmospheres: Analysis of data from International Consortium for Atmospheric Research on Transport and Transformation 2004, J. Geophys. Res.-Atmos., 111, D23S45, doi:10.1029/2005JD006880, 2006.

Stefan, M. I. and Bolton, J. R.: Reinvestigation of the acetone degradation mechanism in dilute aqueous solution by the UV/H2O2 process, Environ. Sci. Technol., 33, 870-873, 1999.

Surratt, J. D., Murphy, S. M., Kroll, J. H., Ng, N. L., Hildebrandt, L., Sorooshian, A., Szmigielski, R., Vermeylen, R., Maenhaut, W., Claeys, M., Flagan, R. C., and Seinfeld, J. H.: Chemical composition of secondary organic aerosol formed from the photooxidation of isoprene, J. Phys. Chem. A, 110, 9665-9690, 2006.

Surratt, J. D., Kroll, J. H., Kleindienst, T. E., Edney, E. O., Claeys, M., Sorooshian, A., Ng, N. L., Offenberg, J. H., Lewandowski, M., Jaoui, M., Flagan, R. C., and Seinfeld, J. H.: Evidence for organosulfates in secondary organic aerosol, Environ. Sci. Technol., 41, 517-527, 2007.

Takekawa, H., Minoura, H., and Yamazaki, S.: Temperature dependence of secondary organic aerosol formation by photo-oxidation of hydrocarbons, Atmos. Environ., 37, 3413-3424, 2003.

Tan, Y., Perri, M. J., Seitzinger, S. P., and Turpin, B. J.: Effects of Precursor Concentration and Acidic Sulfate in Aqueous Glyoxal$\mathrm{OH}$ Radical Oxidation and Implications for Secondary Organic Aerosol, Environ. Sci. Technol., 43, 8105-8112, 2009.
Tan, Y., Carlton, A. G., Seitzinger, S. P., and Turpin, B. J.: SOA from methylglyoxal in clouds and wet aerosols: Measurement and prediction of key products, Atmos. Environ., 44, 5218-5226, 2010.

Tan, Y., Lim, Y. B., Altieri, K. E., Seitzinger, S. P., and Turpin, B. J.: Mechanisms leading to oligomers and SOA through aqueous photooxidation: insights from $\mathrm{OH}$ radical oxidation of acetic acid and methylglyoxal, Atmos. Chem. Phys., 12, 801-813, doi:10.5194/acp-12-801-2012, 2012.

Tiedtke, M.: Representation of Clouds in Large-Scale Models, Mon. Weather Rev., 121, 3040-3061, 1993.

van Donkelaar, A., Martin, R. V., Park, R. J., Heald, C. L., Fu, T. M., Liao, H., and Guenther, A.: Model evidence for a significant source of secondary organic aerosol from isoprene, Atmos. Environ., 41, 1267-1274, 2007.

Volkamer, R., Jimenez, J. L., San Martini, F., Dzepina, K., Zhang, Q., Salcedo, D., Molina, L. T., Worsnop, D. R., and Molina, M. J.: Secondary organic aerosol formation from anthropogenic air pollution: Rapid and higher than expected, Geophys. Res. Lett., 33, L17811, doi:10.1029/2006GL026899, 2006.

Yu, J. Z., Huang, X.-F., Xu, J., and Hu, M.: When Aerosol Sulfate Goes Up, So Does Oxalate:? Implication for the Formation Mechanisms of Oxalate, Environ. Sci. Technol., 39, 128-133, doi:10.1021/es049559f, 2005. 